【総説】

\section{特定保健用食品「食後の血糖 値の上昇を緩やかにする」 表示をした食品について Foods for Specialized Health Use (FOSHU) in Treating Postprandial Elevated Blood Glucose Level}

林 浩孝 ${ }^{1,2, *}$, 大野 智 2 , 新井隆成 ${ }^{3}$, 仲井培雄 ${ }^{4}$, 加藤佳子 ${ }^{2}$, 鈴木信孝 ${ }^{2}$ Hirotaka HAYASHI ${ }^{1,2, *}$, Satoshi OHNO ${ }^{2}$, Takanari $\mathrm{ARAI}^{4}$, Masuo $\mathrm{NAKAI}^{4}$, Yoshio KATO², Nobutaka SUZUKI ${ }^{2}$

1 金沢大学イノベーション創成センター

2 金沢大学大学院医学系研究科臨床研究開発 補完代替医療学講座

${ }^{3}$ 金沢大学附属病院周生期医療専門医養成センター

4 医療法人社団和楽仁 芳珠記念病院

\section{【要 旨】}

「特定保健用食品」のうち, 生活習慣病の 1 つである 糖尿病に関連して「血糖値が高めの方に適する」表示 をした食品については，現在のところ，再許可等特定 保健用食品を含め約 100 種類の商品がある. そのうち のいくつかについて, 安全性・有効性について解説す る.

\section{【キーワード】}

特定保健用食品, 血糖, 関与成分, 難消化性デキスト リン, グアバ葉ポリフェノール，小麦アルブミン，豆 鼓エキス

\section{1.はじめに}

生活習慣病とは，糖尿病・脳卒中・心臓病・高脂血症・ 高血圧・肥満など普段の不規則な生活習慣の積み重齐か ら引き起こされる疾患の総称で，現在，日本人の約 3 分 の 2 がこれらの病気が原因で亡くなっている。そのうち の 1 つである糖尿病は，2002 年 11 月に実施された厚生 労働省の糖尿病実態調査によると, 耐糖能異常を示寸予 備軍を含めると約 1,620 万人と推定されている．この結 果は成人 6.3 人に 1 人の割合とされる ${ }^{1)}$. 現在の食生活, 不規則な生活習慣から考光ると今後ますます増加する一 方であると推測できる，このことから，糖尿病を引き起 こす要因となる血糖值上昇を予防することは重要である.

特定保健用食品の表示許可製品 ${ }^{2}$ のうちの 1 つである 「食後の血糖值の上昇を緩やかにする」と表示された製品 については 2008 年 4 月 24 日現在のものを表 1 亿記載し た。 また，我々は，市販されている製品，又は原料の販 売企業に関連論文等の資料の提供を 2007 年 10 月 1 日か ら依頼し，2008 年 1 月 10 日までに返答のあったものの 一部について, 実施された試験等について今回, 解説する.

\section{2. 血糖上昇について}

主として糖質の利用障害のために高血糖・糖尿が引き 起こされる，糖質のほか，脂肪やタンパク質，電解質の 代謝にも代謝障害が引き起こされる，健常者の空腹時血 糖值 (血中グルコース濃度) は, 約 $80 \mathrm{mg} / \mathrm{dL}(70 \sim 110 \mathrm{mg} /$ dL) で，食後は上昇するが $140 \mathrm{mg} / \mathrm{dL}$ を超えることはな いとされている，血糖を上昇させるホルモンは多様であ るが，低下させるホルモンはインスリンのみで，腎臓中 のグルコース排出閾值を越えると腎蔵から糖が尿に排出 されることになり，これが糖尿であるといわれている11.

\section{3. 血糖値上昇抑制を示す食品中の関与成分}

「食後の血糖値の上昇を緩やかにする」に認められてい る関与成分には，大きく分類して「難消化性デキストリ ン」,「グアバ葉ポリフェノール」,「小麦アルブミン」,「豆

受理日：2008 年 5 月 1 日

* =920-8460 金沢市宝町 13-1 金沢大学大学院医学系研究科臨床研究開発補完代替医療学講座 Tel: 076-265-2147 Fax: 076-234-4247 E-mail: euglena1234@yahoo.co.jp 
表 1 「食後の血糖值の上昇を緩やかにする」表示をした特定保健用食品

2008 年 4 月 24 日（平成 20 年 4 月 24 日）現在のもの

\begin{tabular}{|c|c|c|c|c|c|c|c|}
\hline No. & 商品名 & 申請者 & 食品の種類 & 関与する成分 & 区分 & 許可日 & $\begin{array}{l}\text { 許可 } \\
\text { 番号 }\end{array}$ \\
\hline 1 & 糖健茶料 & サンスター株式会社 & 粉末清涼飲料 & 難消化性デキストリン（食物繊維として） & 特保 & 10.5 .20 & 179 \\
\hline 2 & $\begin{array}{l}\text { 血糖の気になりはじめた } \\
\text { 人のフィッライフコー } \\
\text { ヒー }\end{array}$ & 株式会社ミル総本社 & 粉末清涼领料 & 難消化性デキストリン（食物繊維として） & 特保 & 11.11.22 & 243 \\
\hline 3 & ヤクルト蕃爽麗茶 & 株式会社ヤクルト本社 & 茶系飲料 & グァバ葉ポリフェノール & 特保 & 11.12 .24 & 247 \\
\hline 4 & $\begin{array}{l}\text { 食事のおと搽 } \\
\text { 入り緑䓹物繊維 } \\
\end{array}$ & $\begin{array}{l}\text { 日清サイエンス株式会 } \\
\text { 社 }\end{array}$ & 茶系飲料 & 難消化性デキストリン（食物繊維として） & 特保 & 11.12 .24 & 248 \\
\hline 5 & ミキグルコエイド & 三基商事株式会社 & 乾燥スープ & 小麦アルブミン & 特保 & 12.3 .28 & 257 \\
\hline 6 & グルコデザイン & 日清ファルマ株式会社 & 乾燥スープ & 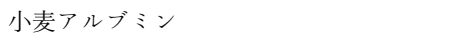 & 特保 & 12.3 .28 & 258 \\
\hline 7 & 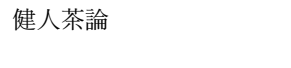 & $\begin{array}{l}\text { 近畿コカ・コーラボト } \\
\text { リング株式会社 }\end{array}$ & 茶系飲料 & 難消化性デキストリン（食物繊維として） & 特保 & 12.3 .28 & 260 \\
\hline 8 & RY 流糖茶 & 有限会社健康社 & $\begin{array}{l}\text { 茶系飲料 } \\
(\text { (ティーバッグ) }\end{array}$ & 難消化性デキストリン（食物繊維として） & 特保 & 12.6 .12 & 268 \\
\hline 9 & 改善生活 GL & エスエス製薬株式会社 & 清涼飲料水 & 難消化性デキストリン（食物繊維として） & 特保 & 12.7.17 & 277 \\
\hline 10 & あなたの味方 & 三井製糖株式会社 & $\begin{array}{l}\text { テーブルシュ } \\
\text { ガー }\end{array}$ & L-アラビノース & 特保 & 12.10 .10 & 288 \\
\hline 11 & 健やか豆腐 & $\begin{array}{l}\text { 株式会社ライクスタカ } \\
\text { ギ }\end{array}$ & とらふ & 難消化性デキストリン（食物繊維として） & 特保 & 12.12 .12 & 297 \\
\hline 12 & 松谷の扔みそ汁合わせ & 松谷化学工業株式会社 & 即席みそ汁 & 難消化性デキストリン（食物繊維として） & 特保 & 12.12 .12 & 301 \\
\hline 13 & 松谷のおみそ汁赤だし & 松谷化学工業株式会社 & 即席みそ汁 & 難消化性デキストリン（食物繊維として） & 特保 & 12.12 .12 & 302 \\
\hline 14 & 松谷の扔みそ汁白みそ & 松谷化学工業株式会社 & 即席みそ汁 & 難消化性デキストリン（食物繊維として） & 特保 & 12.12 .12 & 303 \\
\hline 15 & ピオテア粉末ほうじ茶 & 大和薬品株式会社 & 粉末清涼飲料 & 難消化性デキストリン（食物繊維として） & 特保 & 13.2.16 & 322 \\
\hline 16 & ピオテアドリンク & 大和薬品株式会社 & 清涼飲料水 & 難消化性デキストリン（食物繊維として） & 特保 & 13.2.16 & 323 \\
\hline 17 & Dr. のむヨーグルト & 日本ルナ株式会社 & はっ酵乳 & 難消化性デキストリン（食物繊維として） & 特保 & 13.4.11 & 348 \\
\hline 18 & デュエッティ & $\begin{array}{l}\text { 株式会社三和化学研究 } \\
\text { 所 }\end{array}$ & 茶系飲料 & 難消化性デキストリン（食物繊維として） & 特保 & 13.8 .27 & 359 \\
\hline 19 & 食前茶 & $\begin{array}{l}\text { 日本サプリメント株式 } \\
\text { 会社 }\end{array}$ & 粉末清涼飲料 & 豆鼓エキス & 特保 & 13.10 .18 & 385 \\
\hline 20 & ミキ グルコエイド K & 三基商事株式会社 & 乾燥スープ & 小麦アルブミン & 特保 & 14.1 .21 & 408 \\
\hline 21 & クロスタニンの找茶 & 株式会社日健総本社 & 茶系飲料 & 難消化性デキストリン（食物繊維として） & 特保 & 14.1.21 & 410 \\
\hline 22 & からだサポートごはん & 亀田製菓株式会社 & 米飯類（白飯） & 難消化性デキストリン（食物繊維として） & 特保 & 14.2 .20 & 411 \\
\hline 23 & 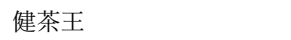 & カルピス株式会社 & 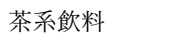 & 難消化性デキストリン（食物繊維として） & 特保 & 14.2 .20 & 412 \\
\hline 24 & 健康笑顔ごはん & エスビー食品株式会社 & 米飯類（白飯） & 難消化性デキストリン（食物繊維として） & 特保 & 14.3 .25 & 417 \\
\hline 25 & クロスタニンのお茶 500 & 株式会社日健総本社 & 茶系飲料 & 難消化性デキストリン（食物繊維として） & 特保 & 14.4 .22 & 421 \\
\hline 26 & 緑茶習慣 & 株式会社伊藤園 & 茶系飲料 & 難消化性デキストリン（食物繊維として） & 特保 & 14.5.27 & 424 \\
\hline 27 & $\begin{array}{l}\text { 緑茶習慣 スティックタ } \\
\text { スプ }\end{array}$ & 株式会社伊藤園 & 粉末清涼飲料 & 難消化性デキストリン（食物繊維として） & 特保 & 14.6.28 & 426 \\
\hline 28 & パインファイバー & 松谷化学工業株式会社 & 粉末 & 難消化性デキストリン（食物繊維として） & 特保 & 14.6.28 & 431 \\
\hline 29 & $\begin{array}{l}\text { 活き活き生活（いきいき } \\
\text { せいから）GL }\end{array}$ & 株式会社丸和 & 清涼飲料水 & 難消化性デキストリン（食物繊維として） & 特保 & 14.8 .16 & 434 \\
\hline 30 & 京優茶＼cjkstart緑茶 ～～～～～～～～～ & アークレイ株式会社 & 茶系飲料 & 難消化性デキストリン（食物繊維として） & 特保 & 14.8 .16 & 435 \\
\hline 31 & 京優膳 合わせみそ & アークレイ株式会社 & 即席みそ汁 & 難消化性デキストリン（食物繊維として） & 特保 & 14.9.30 & 436 \\
\hline 32 & $\begin{array}{l}\text { カラダ支援飲料 ブレン } \\
\text { ド茶 }\end{array}$ & ネスレ日本株式会社 & 茶系飲料 & 難消化性デキストリン（食物繊維として） & 特保 & 14.9 .30 & 438 \\
\hline 33 & グルコケア & 大正製薬株式会社 & 清涼飲料水 & 難消化性デキストリン（食物繊維として） & 特保 & 14.11.18 & 445 \\
\hline 34 & グルコサポート & 大正製薬株式会社 & 清涼飲料水 & 難消化性デキストリン（食物繊維として） & 特保 & 14.12 .6 & 447 \\
\hline 35 & ゆったり健糖＼cjkstart改善生活 & エスエス製薬株式会社 & 清涼飲料水 & 難消化性デキストリン（食物繊維として） & 特保 & 14.12.6 & 456 \\
\hline 36 & 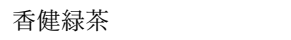 & ネスレ日本株式会社 & 茶系飲料 & 難消化性デキストリン（食物繊維として） & 特保 & 15.3 .6 & 469 \\
\hline 37 & 京優膳 白みそ & アークレイ株式会社 & 即席みそ汁 & 難消化性デキストリン（食物繊維として） & 特保 & 15.6 .11 & 486 \\
\hline 38 & 京優膳 お吸いもの & アークレイ株式会社 & 乾燥スープ & 難消化性デキストリン（食物繊維として） & 特保 & 15.6 .11 & 487 \\
\hline 39 & 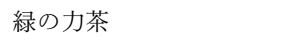 & 株式会社佐藤園 & 粉末清涼飲料 & 難消化性デキストリン（食物繊維として） & 特保 & 15.6 .11 & 488 \\
\hline 40 & グルコイーズ & $\begin{array}{l}\text { ニュースキンジャパン } \\
\text { 株式会社 }\end{array}$ & 粉末清涼领料 & 難消化性デキストリン（食物繊維として） & 特保 & 15.6 .11 & 490 \\
\hline 41 & $\begin{array}{l}\text { ピオテアドリンク粉末夕 } \\
\text { イプ }\end{array}$ & 大和薬品株式会社 & 粉末清涼飲料 & 難消化性デキストリン（食物繊維として） & 特保 & 15.6.11 & 491 \\
\hline 42 & グルコバスター & 日清ファルマ株式会社 & 乾燥スープ & 小麦アルブミン & 特保 & 15.6 .11 & 498 \\
\hline 43 & $\begin{array}{l}\text { ゆったり健糖 改善生活 } \\
\text { (紅茶風味) }\end{array}$ & エスエス製薬株式会社 & 清涼飲料水 & 難消化性デキストリン（食物繊維として） & 特保 & 15.9.25 & 522 \\
\hline 44 & $\begin{array}{l}\text { ゆったり健糖 改善生活 } \\
\text { (ザクロ風味) }\end{array}$ & エスエス製薬株式会社 & 清涼飲料水 & 難消化性デキストリン（食物繊維として） & 特保 & 15.9 .25 & 523 \\
\hline 45 & 快元生活 & 株式会社丸和 & 清涼飲料水 & 難消化性デキストリン（食物繊維として） & 特保 & 15.9 .25 & 524 \\
\hline 46 & ファイバーパワー & 株式会社丸和 & 清涼飲料水 & 難消化性デキストリン（食物繊維として） & 特保 & 15.9 .25 & 525 \\
\hline 47 & クロスタニンの鳥龍茶 & 株式会社日健総本社 & 茶系飲料 & 難消化性デキストリン（食物繊維として） & 特保 & 15.9 .25 & 530 \\
\hline
\end{tabular}


豆鼓エキスつぶタイプ日本サプリメント株式 錠菓

会社

49 タクティ IS

50 ディナーエイド IS

51 天の葉

52 ファイバーパーラー

55 颯爽

56 ファイバーヘルス

57 蹴糖茶

クロスタニンのさわやか 飲料

59 健やか実りごはん

60 水々しあ

61 食事と一緒に十六茶

62 活き活き生活（いきいき せいから）GLII

63 京優粥 京水菜の卵がゆ

64 賢者の食卓

65 サポートヨーグルト

66 健茶王 緑茶

67 天の葉緑茶

68 賢膳緑茶

69 松谷のおそば

70 グルコケア 粉末スティッ ク

71 からだ㡻援ロール

京優 SOUP イタリア産
トマトを使った欧風トマ トスープ

73 京優 SOUP 京野菜九条 ネギ入り中華風春雨スー プ

74 ライフナビ食物繊維入り ほらじ茶

\section{リメイク緑茶}

76 7

77 ホットファイバー

チアライフ

9 ペプチド爽茶

カトキチいきいきごはん

\section{食物繊維入り粉末緑茶}

ころあい

トーチミン

マイルディナー

ノーブルリッチ

じんわり香るあったか スープ

87 食物せんいのオニオン風 スープ

88 健茶王 紅茶

89 健茶王 280

90 健茶王 緑茶 280

91 食後のとう番

92 らるウォーター 食物繊 維

93 さらっとさらり茶

94 グルコセーバー

95 ユピテル食物繊維入りほ らじ茶

96 デキストリンプラス

97 よもぎ生活

98 よもぎ茶びじん

99 娛蓬美茶

100 よもぎ茶物語

アークレイ株式会社
ロート製薬株式会社

ロート製薬株式会社

富士産業株式会社

宝酒造株式会社

日本コカ・コーラ株式 茶系领料

会社

株式会社丸和清涼领料水

株式会社りコム

茶系飲料

朱式会社日健総本社

清涼飲料水

エスビー食品株式会社 米飯類（白飯）

サントリー株式会社

アサヒ飲料株式会社

株式会社丸和

清涼领料水

茶系飲料

清涼领料水

アークレイ株式会社乾燥かゆ

松谷化学工業株式会社 粉末

高梨乳業株式会社咞酵乳

カルピス株式会社茶系飲料

富士産業株式会社粉末清涼领料

森永乳業株式会社茶系飲料

松谷化学工業株式会社 乾め几

大正製薬株式会社

敷島製パン株式会社

アークレイ株式会社

乾燥スープ

粉末清涼飲料

パン

乾燥スープ

ゼリア新薬工業株式会 粉末清涼飲料

社

協和発酵工業株式会社 粉末清涼飲料

株式会社東洋新薬

株式会社東洋新薬

株式会社東洋新薬

仙味エキス株式会社

株式会社加卜吉

株式会社小谷穀粉

汇崎グリコ株式会社

キューサイ株式会社

株式会社東洋新薬

株式会社東洋新薬

株式会社東洋新薬

株式会社東洋新薬

カルピス株式会社

カルピス株式会社

カルピス株式会社

株式会社上薬研究所

乾燥スープ

乾燥スープ

乾燥スープ

茶系飲料

米飯類 (白飯)

粉末清涼飲料

米菓

錠菓

乾燥スープ

乾燥スープ

乾燥スープ

乾燥スープ

茶系飲料

茶系飲料

茶系飲料

乾燥スープ

清涼飲料水

クストステージ株式会

社

新日本製薬株式会社茶系飲料

株式会社東洋新薬乾燥スープ

田村薬品工業株式会社 粉末清涼领料

サントリー株式会社

株式会社東洋新薬

株式会社東洋新薬

株式会社東洋新薬

株式会社東洋新薬

清涼领料水

粉末清涼飲料

粉末清涼飲料

粉末清涼飲料
豆鼓エキス

再許可等特保 $\quad 15.9 .25 \quad 531$

難消化性デキストリン（食物䋐維として）

難消化性デキストリン（食物纎維として）

難消化性デキストリン（食物繊維として）

難消化性デキストリン（食物繊維として）

難消化性デキストリン（食物繊維として）

難消化性デキストリン（食物繊維として）

難消化性デキストリン（食物䋐維として）

難消化性デキストリン（食物繊維として）

難消化性デキストリン（食物繊維として）

難消化性デキストリン（食物瀻維として）

難消化性デキストリン（食物繊維として）

難消化性デキストリン（食物繊維として）

難消化性デキストリン（食物纎維として）

難消化性デキストリン（食物繊維として）

難消化性デキストリン（食物繊維として）

難消化性デキストリン（食物繊維として）

難消化性デキストリン（食物繊維として）

難消化性デキストリン（食物䋐維として）

難消化性デキストリン（食物繊維として）

難消化性デキストリン（食物繊維として）

難消化性デキストリン（食物繊維として）

難消化性デキストリン（食物繊維として）

難消化性デキストリン（食物纎維として）

特保

15.9.25 538

特保 $\quad 15.9 .25 \quad 540$

特保 $\quad 15.9 .25 \quad 543$

特保 $\quad 15.9 .25 \quad 544$

再許可等特保 $\quad 16.1 .8 \quad 548$

再許可等特保 $\quad 16.1 .8 \quad 551$

再許可等特保 $16.1 .8 \quad 552$

特保 $\quad 16.1 .8 \quad 553$

特保 $\quad 16.1 .30 \quad 555$

特保 $\quad 16.8 .20 \quad 588$

再許可等特保 $\quad 16.9 .27 \quad 601$

特保 $\quad 16.11 .12 \quad 609$

特保 $\quad 16.12 .16 \quad 626$

再許可等特保 $17.1 .31 \quad 636$

再許可等特保 $17.3 .29 \quad 643$

特保 $\quad 17.3 .29 \quad 650$

再許可等特保 $17.4 .27 \quad 656$

特保 $\quad 17.5 .30 \quad 663$

再許可等特保 $\quad 17.7 .25 \quad 668$

再許可等特保 $17.7 .25 \quad 672$

再許可等特保 $\quad 17.7 .25 \quad 681$ 再許可等特保 $17.11 .17 \quad 700$

難消化性デキストリン（食物繊維として）

難消化性デキストリン（食物繊維として）

難消化性デキストリン（食物繊維として）

難消化性デキストリン（食物繊維として）

難消化性デキストリン（食物繊維として）

サーデンペプチド (バリルチロシンとして)

難消化性デキストリン（食物纎維として）

難消化性デキストリン（食物繊維として）

難消化性デキストリン（食物繊維として）

豆鼓エキス

難消化性デキストリン（食物繊維として）

難消化性デキストリン（食物繊維として）

難消化性デキストリン（食物纎維として）

難消化性デキストリン（食物繊維として）

難消化性デキストリン（食物繊維として）

難消化性デキストリン（食物繊維として）

難消化性デキストリン（食物瀻維として）

難消化性デキストリン（食物繊維として）

難消化性デキストリン（食物繊維として）

難消化性デキストリン（食物瀻維として）

難消化性デキストリン（食物繊維として）

難消化性デキストリン（食物瀻維として）

難消化性デキストリン（食物繊維として）

難消化性デキストリン（食物繊維として）

難消化性デキストリン（食物繊維として）

難消化性デキストリン（食物繊維として）

難消化性デキストリン（食物繊維として）
再許可等特保 $\quad 17.11 .17 \quad 701$

再許可等特保 $\quad 17.12 .9 \quad 714$

再許可等特保 $\quad 18.2 .21 \quad 726$ 規格基準型特 $18.2 .21 \quad 732$

特保 $\quad 18.2 .21 \quad 733$

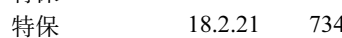

再許可等特保 $\quad 18.2 .21 \quad 736$

特保 $\quad 18.2 .21 \quad 737$

特保 $\quad 18.6 .15 \quad 752$

特保 $\quad 18.6 .15 \quad 755$

特保 $\quad 18.8 .30 \quad 763$

再許可等特保 $\quad 18.11 .22 \quad 791$

再許可等特保 $\quad 18.11 .22 \quad 792$

再許可等特保 $\quad 19.1 .29 \quad 813$

再許可等特保 $\quad 19.1 .29 \quad 815$

再許可等特保 $\quad 19.1 .29 \quad 816$

特保 $\quad 19.1 .29 \quad 817$

特保 $\quad 19.2 .16 \quad 829$

特保 $\quad 19.2 .16 \quad 830$

再許可等特保 $\quad 19.4 .17 \quad 861$

再許可等特保 $19.4 .17 \quad 863$

再許可等特保 $\quad 19.4 .17 \quad 867$

特保 $\quad 19.6 .18 \quad 884$

特保 $\quad 19.6 .18 \quad 885$

特保 $\quad 19.6 .18 \quad 886$

特保 $\quad 19.6 .18 \quad 888$
再許可等特保 $19.1 .29 \quad 812$

特保 $\quad 19.6 .18 \quad 887$ 


\begin{tabular}{|c|c|c|c|c|c|c|c|}
\hline 101 & よもぎ畑の贈り物 & 株式会社東洋新薬 & 粉末清涼领料 & 難消化性デキストリン（食物繊維として） & 特保 & 19.6.18 & 889 \\
\hline 102 & $\begin{array}{l}\text { リカルデント アップル\& } \\
\text { アップルミント }\end{array}$ & $\begin{array}{l}\text { キャドバリー・ジャパ } \\
\text { ン株式会社 }\end{array}$ & チューインガム & CPP-ACP（乳たんぱく分解物） & 特保 & 19.6.18 & 893 \\
\hline 103 & ファイバーイン & $\begin{array}{l}\text { 日本コカ・コーラ株式 } \\
\text { 会社 }\end{array}$ & 果実飲料 & 難消化性デキストリン（食物繊維として） & 規格基準型特 & 19.6.29 & 894 \\
\hline 104 & ファイバーイン 190 & $\begin{array}{l}\text { 日本コカ・コーラ株式 } \\
\text { 会社 }\end{array}$ & 果実飲料 & 難消化性デキストリン（食物繊維として） & 替格基準型特 & 19.6.29 & 895 \\
\hline 05 & デキストリンプラス & サントリー株式会社 & 清涼领料水 & 難消化性デキストリン（食物繊維として） & 特保 要 & 19.7.27 & 898 \\
\hline 106 & よもぎ生活 & 株式会社東洋新薬 & 粉末清涼飲料 & キストリン（食物繊維として） & 特保 & 19.7.27 & 899 \\
\hline 107 & 上斥 & k式全 & 粉末: & キストリン（食物䋐維として） & 特保 & 19.7.27 & 900 \\
\hline 108 & 娛蓬美茶 & 薬 & 粉末清 & キストリン（食物繊維として） & 特保 & 19.7.27 & 901 \\
\hline 109 & よもぎ & 薬 & 粉末i & 難消化性デキストリン（食物繊維として） & 特保 & 19.7.27 & 902 \\
\hline 10 & 日の贈り物 & 洋新薬 & 粉末: & 難消化性デキストリン（食物繊維として） & 特保 & 19.7.27 & 903 \\
\hline 111 & デキストリン珈琲 & ママサン & 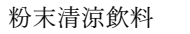 & 難消化性デキストリン（食物繊維として） & 再許可等特保 & 19.10.4 & 924 \\
\hline 112 & 健茶王＼cjkstart紅茶 280 & カルピス株式会社 & 茶系飲料 & 難消化性デキストリン（食物繊維として） & 特保 & 19.10 .23 & 944 \\
\hline 113 & $\begin{array}{l}\text { このごろ気になる自分の } \\
\text { 生活 }\end{array}$ & $\begin{array}{l}\text { 日本たばこ産業株式会 } \\
\text { 社 }\end{array}$ & コーヒ一飲料 & 難消化性デキストリン（食物繊維として） & 特保 & 19.12 .4 & 959 \\
\hline 114 & グルコカット & 株式会社カイゲン & & 難消化性デキストリン（食物繊維として） & 特保 & 20.2 .8 & 978 \\
\hline 115 & グルコカット G & 株式会社カイゲン & 茶系飲料 & 難消化性デキストリン（食物繊維として） & 特保 & 20.2 .8 & 979 \\
\hline 116 & カラダはずむほうじ茶 & $\begin{array}{l}\text { アサヒフードアンドへ } \\
\text { ルスケア株式会社 }\end{array}$ & 粉末清涼飲料 & 難消化性デキストリン（食物瀻維として） & 再許可等特保 & 20.3 .11 & 989 \\
\hline 117 & ハッピーファイバー & 株式会社東洋新薬 & 粉末 & 難消化性デキストリン（食物繊維として） & 再許可等特保 & 20.4 .9 & 1006 \\
\hline
\end{tabular}

鼓エキス」がある。

それぞれの作用機序を簡略に述べる。

(1)「難消化性デキストリン」

難消化性デキストリンは, 乾燥デンプンを $120 \sim 180^{\circ} \mathrm{C}$ の高温で加熱し，グリコシド結合の一部が切断され，再 重合が進むにつれ, 結合部の変換が起こり, 枝分かれ構 造が増加したものである ${ }^{3)}$.

ラット空腸より単離した翻転小腸を用いて難消化性デ キストリンのグルコース・ショ糖の消化吸収に及ぼす影 響を検討した結果，ショ糖由来のグルコースの輸送を阻 害していることが見出され，単糖類に影響を及ぼさない が，二糖類以上の糖質に対して血糖上昇抑制効果を示す ことが確認されている4)。 また，ラット，及びヒトへの ショ糖負荷試験においても, 翻転小腸試験と同様に, 単 糖類に影響を及ぼさないが，二糖類以上の糖質に対して 血糖上昇抑制効果を示すことが確認されている4).

(2)「グアバ茶ポリフェノール」

グアバはフトモモ科バンジロウ属に属する常緑樹であ り，熱帯，亜熱帯地方に広く自生する．グアバ葉の抽出 エキスが糖類分解酵素の 1 つである $\alpha$-アミラーゼ阻害活 性を持つことが報告されている5)。 $\alpha$-アミラーゼ阻害物 質は, 抗肥満, 抗糖尿病への利用が試みられ, デンプン の消化・吸収を阻害することにより血糖值やインスリン の上昇を抑制し，抗肥満・抗糖尿病薬として有用である ことが報告されている6,7).

(3)「小麦アルブミン」

小麦アルブミンとは，名の通り小麦の中の水溶性タン パク質で，電気泳動で分析すると，0.19の位置にピーク がある小麦アルブミンを「0.19 小麦アルブミン」という。
この「0.19 小麦アルブミン」が小麦アルブミン画分の主 成分となり，ヒト唾液及び膵蔵アミラーゼの阻害活性を 示し，消化管内のアミラーゼ活性を一時的に低下させる ことにより血中グルコース濃度の上昇を抑制すると報告 されている ${ }^{8,9}$. 小麦アルブミン 1 分子がアミラーゼ 1 分 子と結合して阻害活性を示すことが明らかになってい $ろ^{10)}$.

(4)「豆鼓エキス」

$\alpha$-グリコシダーゼの阻害により血糖值上昇抑制作用を 示すといわれている ${ }^{11,12)}$. 正常ラットへの単回投与を 60 日間実施したところ，用量依存的に血糖值上昇が抑制さ れ, 投与開始 50 日後の糖負荷試験に打いて血糖值の上昇 が用量依存的に抑制されたと報告されている11)。試験終 了時のインスリン值も低值を示したため, 血糖值の改善 作用が明らかとなっている12).

\section{4.「食後の血糖値の上昇を緩やかにする」表示された 商品について}

\section{1. 安全性試験について}

以下に，例としての関与成分の安全性に関する試験に ついて記す.

（1）難消化性デキストリン含有粉末スープの安全性試 験 ${ }^{13)}$ (株式会社東洋新薬)

(1)方法

1) 対象者

健常成人 10 名（男/女 ; 4/6, 平均年齢 : $32.9 \pm 7.3$ 歳)

2) 被験食・摂取方法

難消化性デキストリンにタマネギエキス，チキンコ 
ンソメ, タマネギ発酵エキス，食塩，胡椒などを混合 した顆粒状粉末スープ $8.7 \mathrm{~g}$ を食事とともに 1 日 3 回摂 取.

3) 拱取期間

12 週間

(2)結果

1) 血液生化学的検查・血液学的検査

・総タンパク, アルブミン, GOT (AST), GPT(ALT), $\mathrm{ALP}, \mathrm{LDH}, \mathrm{TC}, \mathrm{Na}, \mathrm{Cl}, \mathrm{K}, \mathrm{Ca}, \mathrm{Mg}$, モモグロビン，赤 血球数, ヘマトクリット, 白血球数及び血小板数で, 摂取前に比して摂取終了後で有意な変化が認められ たがいずれも基準值範囲内の変動であり, 臨床学的 に問題は認められなかった。

また，健常成人及び空腹時血糖值が高めの成人との 間に顕著な差は認められなかった。

- 空腹時血糖值は摂取前と比して摂取 4,12 週間後で 有意な低下が認められた（いずれも $\mathrm{p}<0.001 ）$.

2) 尿検査

・尿比重は摂取前と摂取終了後では有意な増加が認め られたが基準值範囲内の微細な変化であった。

・タンパク，糖，ヶトン体，ウロビリノーゲン及び潜 血に打いては問題は認められなかった。

3) 身体学的検査

- 体脂肪率が摂取前と比して摂取 8, 12 週間後に有意 な低下を示した（8 週間後： $\mathrm{p}<0.05 ， 12$ 週間後： $\mathrm{p}<0.01 ）$ が，一定した変化ではなかった.

・その他の自他覚症状に沶いて問題所見は認められな かった.

従って, 当該被験食は安全性に問題のない食品である ことが確認された。

（2）難消化性デキストリン含有ヨモギ粉末飲料安全性試 験14）（株式会社東洋新薬）

(1)方法

1) 対象者

健常成人 11 名・試験責任医師が糖尿病予備軍と判断 した成人 5 名 計 16 名（男/女；6/10, 平均年齢： $36.6 \pm 8.0$ 歳)

2) 被験食・摂取方法

ファイバーソル2（食物䋐維として 85〜90\%含有す る難消化性デキストリン；松谷化学工業社製）90\%を 配合し，ヨモギ粉末 $4 \%$, 抹茶 $4 \%$, 緑茶抽出物 $2 \%$ を 加え混合後, 造粒し，顆粒状粉末に調製したものを使 用した. 1 包 $6.8 \mathrm{~g}$ に包装して摂取した. 4 包を約 150 $\sim 250 \mathrm{~mL}$ の湯に溶かして食事中または食後 1 時間以内 に 1 日 3 回, 4 週間連続摂取した.

3) 摂取期間
4 週

(2)結果

1) 血液生化学的検查・血液学的検査

・総タンパク (拱取 4 週間後), アルブミン（拱取終了 2 週間後), GOT (拱取 2 週間後), GPT (摂取 2 週 間後), ALP (摂取終了 2 週間後), LDH コレステ ロール (摂取 4 週間後, 摂取終了 2 週間後), BUN (摂取終了 2 週間後), $\mathrm{Na}$ (拱取 4 週間後, 拱取終了 2 週間後), $\mathrm{Cl}$ (摂取 2 週間後, 拱取終了 2 週間後), $\mathrm{Ca}$ (摂取 4 週間後), $\mathrm{Mg}$ (摂取 4 週間後, 摂取終了 2 週間後), 空腹時血糖（摂取 2 週間後，摂取終了 2 週間後)，フルクトサミン（拱取終了 2 週間後）飞掠 いて，拱取前と比して有意な変動を示したが，いず れも基準値範囲内の推移であり，臨床上問題ないと 考えられた。

- 赤血球数 (摂取終了 2 週間後), ヘマトクリット（摂 取終了 2 週間後), 白血球分画 BASO (拱取終了 2 週 間後）で，摂取前に比して摄取終了後で有意な変化 が認められたがいずれも基準值範囲内の推移であ り，臨床上問題ないと考えられた。

2) 尿検查

摂取 4 週間後において摄取前に比して摂取終了後で 有意な変化が認められたが基準值範囲内の推移であ り, 臨床上問題ないと考光られた。

3) その他身体学的検查

- 体重 - 体脂肪率 (摂取 2 週間後), 収縮期血圧 (摂取 4 週間後), 拡張期血圧 (摂取 2, 4 週間後), 脈拍 （摂取 2，4 週間後）に扔いて有意な変動が認められ たが基準值範囲内の推移であり，臨床上問題ないと 考えられた。

・自他覚症状において問題所見は認められなかった。 従って，当該被験食は安全性に問題のない食品である ことが確認された。

(3) 難消化性デキストリン配合粉末緑茶の長期摂取によ る安全性試験 ${ }^{15)}$ （日清オイリオグループ株式会社）

(1)方法

1) 対象者

糖尿病境界型成人 14 人を被験食（下記 2 ）で詳細に 述べる） 3 包摂取群と 6 包摂取群の 2 群にそれぞれ 7 人ずつに分けた。詳細を下記に示す。

\begin{tabular}{|l|c|c|c|c|}
\hline & $\begin{array}{c}\text { 人数 } \\
\text { (男/女) }\end{array}$ & $\begin{array}{c}\text { 平均年齢 } \\
\text { (歳) }\end{array}$ & $\begin{array}{c}\text { 平均空腹時血糖 } \\
(\mathrm{mg} / \mathrm{dL})\end{array}$ & $\begin{array}{c}\text { 平均 OGTT } \\
\text { 2 時間值 }(\mathrm{mg} / \mathrm{dL})\end{array}$ \\
\hline 3 包群 7 人 $(5 / 2)$ & $52.0 \pm 16.0$ & $107.4 \pm 15.6$ & $189.4 \pm 55.4$ \\
6 包群 & 7 人 $(5 / 2)$ & $51.0 \pm 7.5$ & $110.7 \pm 12.8$ & $174.6 \pm 57.1$ \\
\hline
\end{tabular}

2) 被験食・撕取方法

1 包 $6 \mathrm{~g}$ 中に, 難消化性デキストリン $4.5 \mathrm{~g}$, その他 
緑茶抽出物及び緑茶粉末が配合された粉末を扣湯又は 水に溶かして 1 日 3 包または 6 包摂取した。 3 包摂取 群は毎食事に 1 包ずつ, 6 包拱取群は毎食事に 2 包ず つ摂取した。

3) 摂取期間

12 週間

(2)結果

【1】 1 日 3 包摂取群

1) 経ロブドウ糖負荷試験

摂取 8 週間後の食後 30 分後の血糖値を検討した結

果，摂取前と比して有意に上昇が抑制された $(\mathrm{p}<0.05)$.

2) 生理学的検査

摂取前と摂取終了（12 週間）後の体重・血圧・脈拍 数の有意な変動は認められなかった。

3) 血液生化学的検查・血液学的検査

- 摂取 4 週間後の尿酸, 摂取 12 週間後の $\mathrm{HbA}_{1 \mathrm{c}}$ ・総夕 ンパクに扔いて有意な変動がみられたが，いずれも 正常範囲内での変動で, 臨床上問題はなかった。

・摂取 12 週間後の赤血球数・モモグロビンに扎いて有 意な変動がみられたが，いずれも正常範囲内での変 動で，臨床上問題はなかった。

4) 有害事象

なし。

【2】1 日 6 包摂取群

1) 経ロブドウ糖負荷試験

摂取 8 週間後の食後 30 分後の血糖值を検討した結 果，摂取前と比して有意に上昇が抑制された $(\mathrm{p}<0.05)$. 途中中止した 1 例については中止後のデータは採用し なかった。

2) 生理学的検查

摂取前之摂取終了（12 週間）後の体重・血圧・脈拍 数の有意な変動は認められなかった．途中中止した 1 例については中止後のデータは採用しなかった，

3) 血液生化学的検查・血液学的検査

・摂取 8 週間後の総タンパクに打いて有意な変動がみ られたが，いずれも正常範囲内での変動で，臨床上 問題はなかった.

・赤血球数において有意な変動がみられたが，いずれ も正常範囲内での変動で，臨床上問題はなかった． 途中中止した 1 例については中止後のデータは採用 しなかった。

4) 有害事象

摂取 4 週間後に 1 例，便秘症状がみられ，試験を中 止した．医師により，被験食との関連性は否定できな いと判断された.

（4）難消化性デキストリン配合ブレンド茶の安全性試
験16）（アサヒ飲料株式会社）

(1)方法

1) 対象者

健常成人で空腹時血糖値が基準值内の者 15 名（男/ 女 : $7 / 8$, 平均年齢 : $39.1 \pm 9.2$ 歳)

2) 被験食・摂取方法

八トムギ，緑茶，大麦，玄米等を混合して熱水抽出

し，ビタミン C と $250 \mathrm{~mL}$ あたりファイバーソル 2 (食 物繊維として 85〜90\%含有する難消化性デキストリ ン; 松谷化学工業社製） $6 \mathrm{~g}$ を配合したブレンド茶を 1 日 3 回食事とともに毎日摂取した。

3) 摂取期間

12 週間

(2)結果

被験者 15 名中 2 名の被験食撕取率が $99 \%$ であった。 そ の他の被験者に関しては摂取率 100\%であった。

1) 血液生化学的検查・血液学的検查

- 摂取 4, 8 週間後, 摂取前に比して HbA1 が有意に低 下した（4 週間後 $\mathrm{p}<0.01 ， 8$ 週間後 $\mathrm{p}<0.1)$. また， $\mathrm{HbA} 2$ に打いても摂取 4,8 週間後, 摂取前に比して 有意に低下した（いずれも $\mathrm{p}<0.01 ） 。$ しかし，いず れも基準值の範囲内であり, その他の検査值を含め, 低糖值を示唆するよらな変化は認められなかった。

・ $\mathrm{K}, \mathrm{Cu}, \mathrm{Ca}, \mathrm{Cl}, \mathrm{Zn}$ に有意な変化が認められたがいずれ も基準值の範囲内であり，臨床上問題ないと判断さ れた。

・総タンパク質，アルブミン，総ビリルビンが有意な 変動を示したがいずれも基準值範囲内であった。

・肝機能，腎機能に関連した検査值，半定量項目であ る血清 CRP 值には異常変動は夕られなかった.

2) 尿検査 異常変動はみられなかった。

3) 有害事象 被験食摂取に起因すると考兄られる臨床上問題とな る所見は認められなかった。

(5) 難消化性デキストリンを配合した米菓の継続摂取時 の安全性 ${ }^{17)}$ (汇崎グリコ株式会社）

(1)方法

1) 対象者 健常者 12 名（男/女；10/2，平均年齢：37.0 2.8 歳） 2) 被験食・摂取方法

難消化性デキストリン（パインファイバー C ; 松谷 化学株式会社製）24.2\%配合したサラダせんべいを 1 日 $80 \mathrm{~g}$ 摂取した。

3) 摂取期間

4 週間 


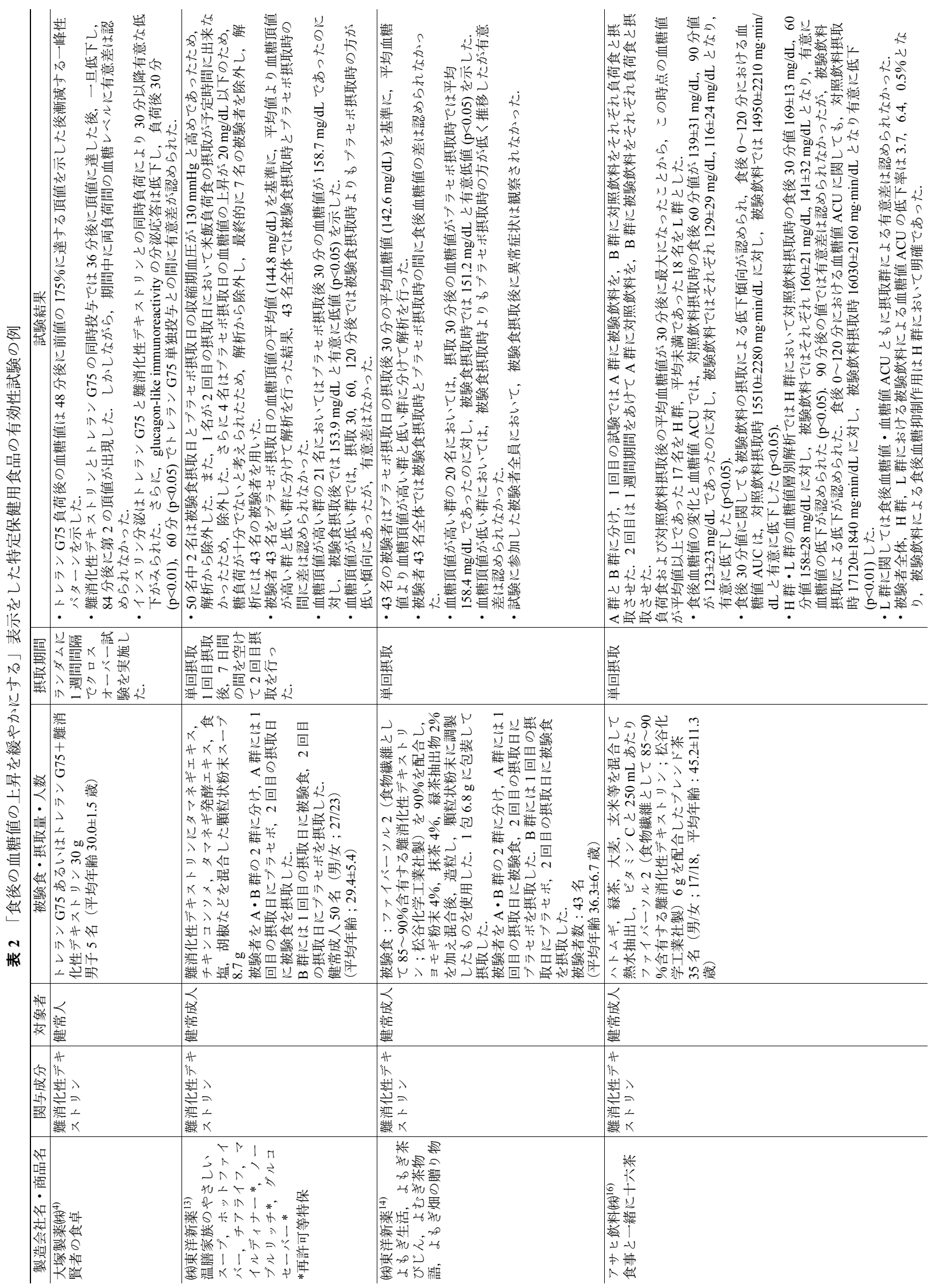




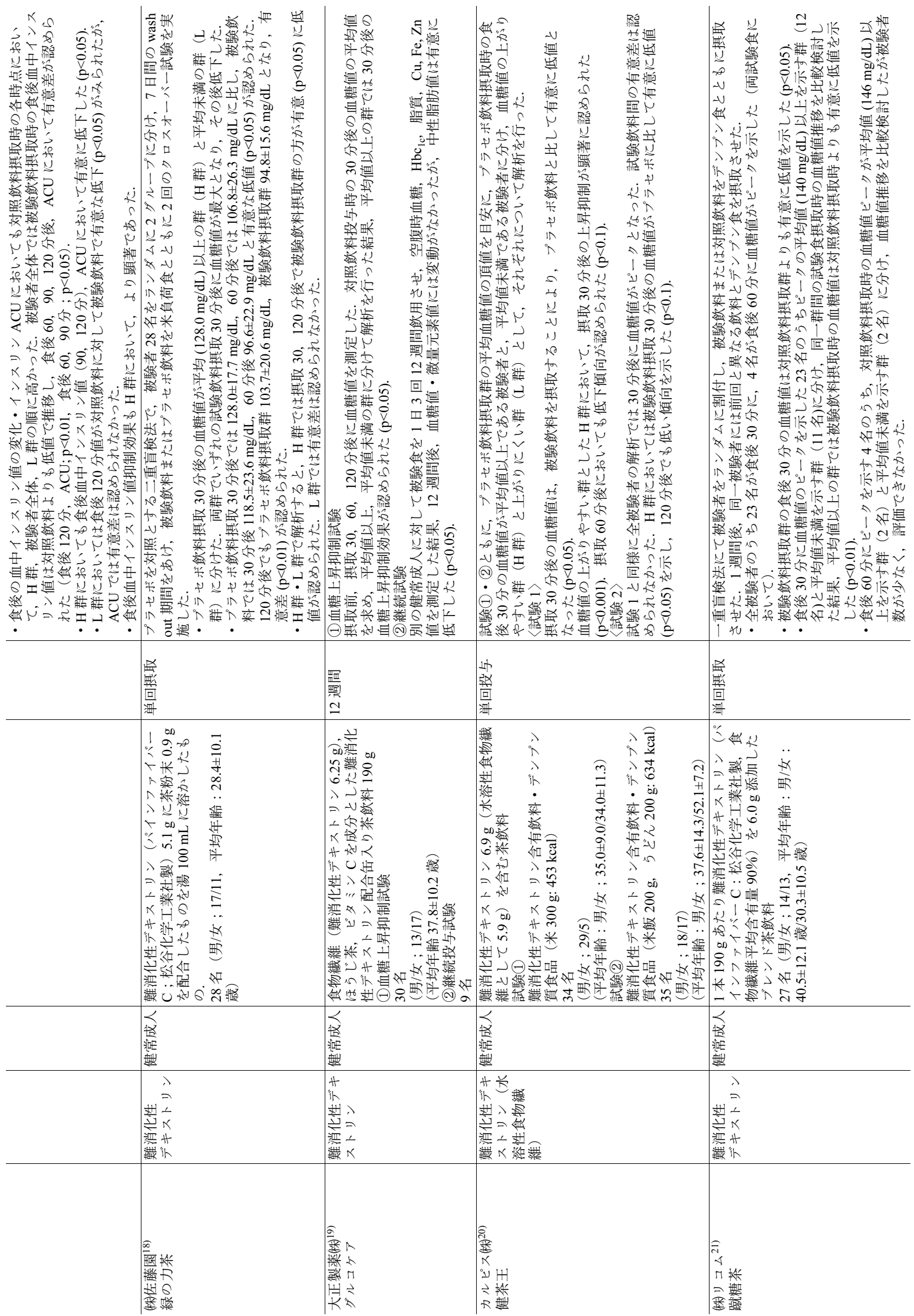




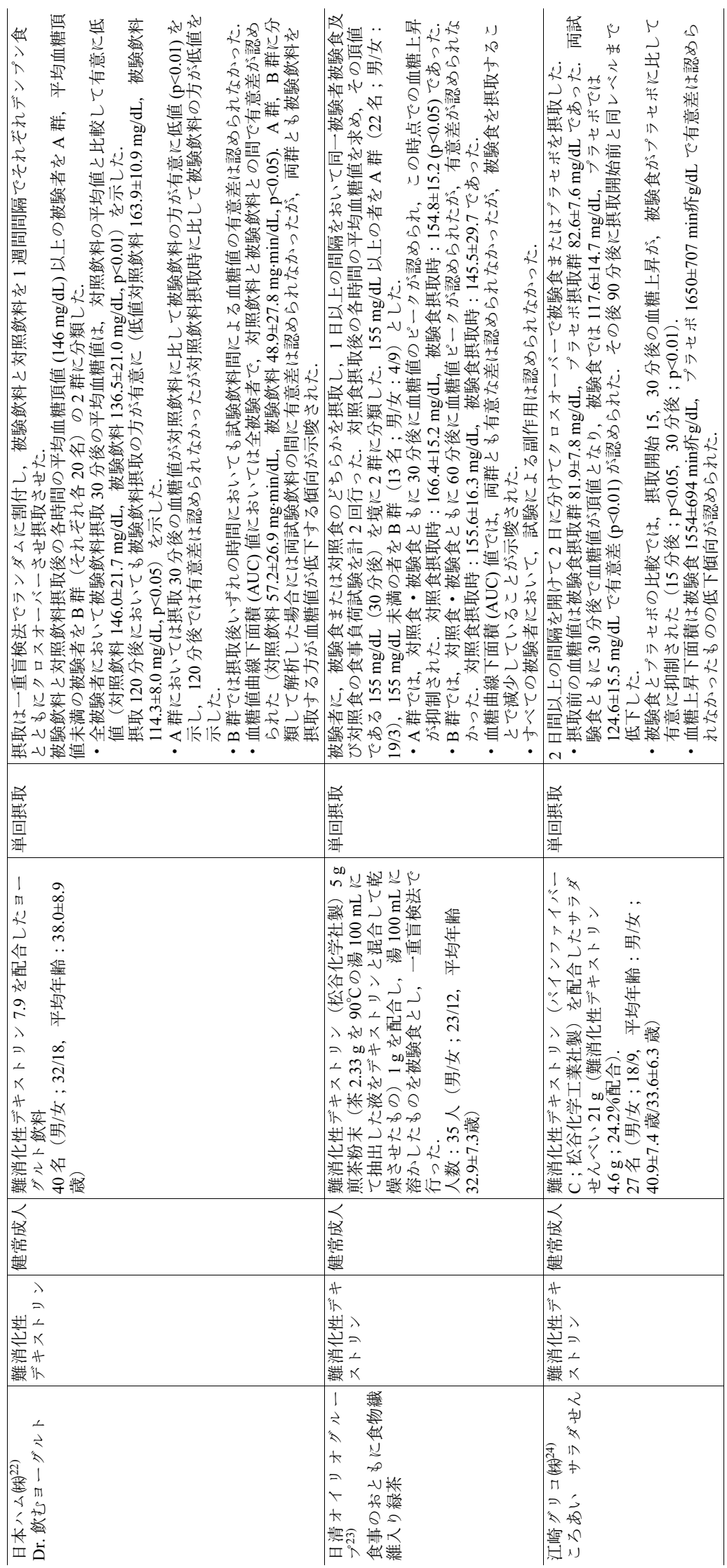


(2)結果

1) 血液生化学的検査・血液学的検査

いくつかの項目で有意な変動がみられたが，いずれ も基準範囲内の微小変動であり，臨床上問題となる所 見でないと判断された.

2) 生理学的検査

有意な変化はみられなかった。

3) 有害事象

試験期間中, 消化器症状の問診において 12 名中 5 名 の被験者に腹部膨満感が現れたが，いずれも一過性の ものであり，日常生活に支障があるものではなく，臨 床上問題となる所見ではないと判断された。 また，被 験食摂取に起因するその他の症状の発現はみられな かった。

（6）難消化性デキストリン含有緑茶飲料の長期摂取によ る安全性試験 ${ }^{18)}$ (株式会社佐藤園)

(1)方法

1) 対象者

健常成人 10 名（男/女 ; 5/5, 平均年齢 : $36.0 \pm 10.3$ 歳）

2) 被験食・撕取方法

難消化性デキストリン（パインファイバー C ; 松谷
化学株式会社製） $5.1 \mathrm{~g}$ に茶粉末 $0.9 \mathrm{~g}$ を配合したもの を敃湯 $100 \mathrm{~mL}$ に溶かし，1日3 回摂取した。

3) 摂取期間

12 週間

(2)結果

1) 血液生化学的検査・血液学的検査

- GOT 值が拱取 12 週間後に有意に低下したが，基準 值の範囲内であった。

・中性脂肪は摂取 4 週間後で基準值を超えたが，これ は被験者の 1 人が中性脂肪值が摂取前から異常に高 く，特に 4 週間後で最高值となったためである.こ の 1 人を除いた 9 人について解析したところ，すべ て基準值内であった

2) 有害事象

安全上問題となる所見は認められなかった.

\section{2. 有効性試験について}

有効性試験については表 2 に製造会社名, 商品名, 関 与成分，対象者，被験食・摂取量 - 人数，摂取期間，試 験結果等について概略を記した ${ }^{4,13,14,16,18,19-24)}$. 尚，血糖 值の推移については, 日本八ム(株) 22 , 日清オイリオグルー

(A) 被験者の分類

表 3.1 日本八ム秼) 商品名：「Dr. 飲むヨーグルト」 ${ }^{22}$

\begin{tabular}{|c|c|c|c|}
\hline 被験者 & 人数（男/女）（人） & 負荷食摂取後の血糖值 $(\mathrm{mg} / \mathrm{dL})$ & 平均年齢（歳） \\
\hline 全例 & $40(32 / 8)$ & & $38.0 \pm 8.9$ \\
\hline A 群（血糖の上がりやすい群） & $20(18 / 2)$ & $\geqq 146$ & $41.5 \pm 8.7$ \\
\hline B 群（血糖の上がりにくい群） & $20(14 / 6)$ & $<146$ & $34.5 \pm 7.8$ \\
\hline
\end{tabular}

(B) 難消化デキストリン配合ヨーグルト飲料摂取による食後血糖上昇の及ぼす影響

\begin{tabular}{|c|c|c|c|c|c|c|}
\hline \multirow{2}{*}{ 時間（分） } & \multicolumn{2}{|c|}{ 全被験者 $\quad(\mathrm{N}=40)$} & \multicolumn{2}{|c|}{ A 群 $\quad(\mathrm{N}=20)$} & \multicolumn{2}{|c|}{ B 群 $\quad(\mathrm{N}=20)$} \\
\hline & 対照食 (mg/dL) & 被験食 (mg/dL) & 対照食 (mg/dL) & 被験食 (mg/dL) & 対照食 (mg/dL) & 被験食 $(\mathrm{mg} / \mathrm{dL})$ \\
\hline 30 & $146.0 \pm 21.7$ & $136.5 \pm 21.0$ & $163.9 \pm 10.9$ & $148.7 \pm 17.1$ & \multirow{2}{*}{\multicolumn{2}{|c|}{ 有意差なし }} \\
\hline 120 & $119.1 \pm 7.5$ & $114.3 \pm 8.0$ & 有意 & なし & & \\
\hline
\end{tabular}

(A) 被験者の分類

表 3.2 日清オイリオグループ(侏) 商品名：「食事のおともに食物繊維入り緑茶」 23$)$

\begin{tabular}{lccc}
\hline 被験者 & 人数 (男/女) $($ 人) & 対照食摂取 30 分後の血糖值 $(\mathrm{mg} / \mathrm{dL})$ & 平均年齢（歳） \\
\hline 全例 & $35(23 / 12)$ & & $32.9 \pm 7.3$ \\
A 群（血糖の上がりやすい群） & $22(19 / 3)$ & $\geqq 155$ & $32.4 \pm 7.7$ \\
B 群（血糖の上がりにくい群） & $13(4 / 9)$ & $<155$ & $30.2 \pm 5.8$ \\
\hline
\end{tabular}

(B) 難消化デキストリン添加緑茶摂取による食後血糖上昇の及ぼす影響

\begin{tabular}{|c|c|c|c|c|c|c|}
\hline \multirow{2}{*}{ 時間（分） } & \multicolumn{2}{|c|}{ 全被験者 $\quad(\mathrm{N}=35)$} & \multicolumn{2}{|c|}{ A 群 $\quad(\mathrm{N}=22)$} & \multicolumn{2}{|c|}{$\mathrm{B}$ 群 $\quad(\mathrm{N}=13)$} \\
\hline & 対照食 (mg/dL) & 被験食 (mg/dL) & 対照食 (mg/dL) & 被験食 (mg/dL) & 対照食 (mg/dL) & 被験食 $(\mathrm{mg} / \mathrm{dL})$ \\
\hline 0 & $90.5 \pm 11.0$ & $92.9 \pm 10.8$ & $93.9 \pm 10.0$ & $95.4 \pm 9.8$ & $84.8 \pm 10.2$ & $88.7 \pm 11.0$ \\
\hline 30 & $155.3 \pm 17.9$ & $151.1 \pm 16.3$ & $166.4 \pm 11.4$ & $154.8 \pm 15.2$ & $136.7 \pm 9.4$ & $144.8 \pm 16.1$ \\
\hline 60 & $149.3 \pm 20.4$ & $146.0 \pm 25.2$ & $145.6 \pm 21.6$ & $146.3 \pm 22.1$ & $155.6 \pm 16.3$ & $145.5 \pm 29.7$ \\
\hline 120 & $124.8 \pm 17.8$ & $122.9 \pm 18.2$ & $128.2 \pm 15.3$ & $122.4 \pm 16.0$ & $119.0 \pm 20.1$ & $123.9 \pm 21.4$ \\
\hline
\end{tabular}


表 3.3 江崎グリコ(侏) 商品名：「ころあい サラダせん」 ${ }^{24)}$ 摂取後各時間の血糖値 $(\mathrm{mg} / \mathrm{dL})$

\begin{tabular}{ccc}
\hline 時間 (分) & 被験食 & プラセボ \\
\hline 0 & $81.9 \pm 7.8$ & $82.6 \pm 7.6$ \\
15 & $108.1 \pm 13.9^{*}$ & $112.2 \pm 16.7$ \\
30 & $117.6 \pm 14.7^{* *}$ & $124.6 \pm 15.5$ \\
45 & $105.3 \pm 16.9$ & $105.6 \pm 16.0$ \\
60 & $90.9 \pm 15.5$ & $90.4 \pm 12.0$ \\
75 & $84.2 \pm 10.1$ & $82.6 \pm 9.7$ \\
90 & $79.8 \pm 6.4$ & $78.6 \pm 8.7$ \\
\hline
\end{tabular}

$*_{\mathrm{p}}<0.05, * * \mathrm{p}<0.01$

被験者数 27 人（男/女：18/9），平均年齢 $38.5 \pm 7.8$ 歳（男/女： $40.9 \pm 7.4 / 33.6 \pm 6.3$ )

プ(株 $)^{23)}$, 江崎グリコ(株 ${ }^{24)}$ の血糖值推移について, 表 3.1, 3.2，3.3 に記した.

\section{5. 謝 辞}

本総説を執筆するにあたりまして御協力を頂きました 日清オイリオグループ株式会社, カルピス株式会社, 大 正製薬株式会社, 株式会社佐藤園, 株式会社ミッカン, 株式会社東洋新薬, アサヒ飲料株式会社, 大塚製薬株式 会社, 江崎グリコ株式会社, 株式会社リコムの御担当の 万々に深く御礼を申し上げます。

\section{参 考 文 献}

1) 嶋津 孝, 下田妙子編 臨床栄養学 疾病編. 化学同人. 2004: 66-67.

2) 林 浩孝, 大野 智, 太田康之ら. 特定保健用食品の許認 可について. 日本補完代替医療学会誌. 2007; 4(3): 103-112.

3) 日本栄養 - 食糧学会編 栄養 - 食糧学用語辞典. 建帛社. 2007: 443.

4) 若林 茂. 難消化性デキストリンの耐糖能に及ぼす影響. 日本内分泌学会誌. 1992; 623-635. 1992; 68: 623-635.

5) 井上良計, 細見尚美, 辻田隆広ら. グアバ茶抽出の $\alpha-$ アミ ラーゼインヒビターの作用について. New Food Industry. 1994; 36: 1-7.

6) 出口ヨリ子, 長田邦子, 内田和美ら. グアバ茶熱水抽出物 $\mathrm{db} / \mathrm{db}$ マウスに打ける抗糖尿病効果扎よびヒト飲用試験に よる食後血糖值上昇抑制効果. 日本農芸化学会誌. 1998; 72 : 923-931.

7) Gerard J, Luycky AS, Lefebvre PJ. Improvement of metabolic control in insulin dependent diabetics treated with $\alpha$-glucosidase inhibitor acarbose for two months. Diabetes 1981; 21: 446-451.

8) Kodama T, Miyazaki T, Kitayama I, et al. Effects of single and long-term administration of wheat albumin on blood glucose control: randomized controlled clinical rats. Eur J Clin Nutr 2005; 59: 384-392.
9) Kataoka K, Dimagno EP. Effect of prolonged intraluminal $\alpha$ amylase inhibitions on eating, weight, and the small intestine of rats. Nutrition 1999; 15: 123-129.

10) Oneda $H$, Lee $S$, Inouye $K$. Inhibitory effect of $0.9 \alpha$-amylase inhibitor from wheat kernel on the activity of porcine pancreas $\alpha-$ amylase and its thermal stability. J Biochem 2004; 135: 421-427.

11) Fujita H, Yamagami T, Ohshima K. Fermented soybean-deriver water-soluble Touchi extract inhibits $\alpha$-glucosidase and is antiglycemic in rats and human after single oral treatments. J Nutri 2001; 1311: 1211-1213.

12) Fujita H, Yamagami T. Fermented soybean-deriver Touchi extract with anti-diabetic effect via $\alpha$-glucosidase inhibitory action in a long-term administration study with $\mathrm{KKA}^{\mathrm{y}}$ mice. Life Sci 2001; 70: 219-227.

13) 池口主弥, 伊藤 聖, 神谷智康ら. 難消化デキストリン含 有粉末スープの食後血糖值抢よび長期連続㨟取による安全 性への影響. 日本食品新素材研究会誌. 2005; 9: 57-64.

14) 伊藤 聖, 神谷智康, 草場宣延ら. 難消化デキストリン含 有ヨモギ粉末の食後血糖值への影響および過剩摂取による 安全性. 日本食品新素材研究会誌. 2005; 10: 20-27.

15）長田正久, 高塚洋二. 難消化デキストリン配合粉末緑茶の 長期摂取に打ける血糖值抢よび安全性に対する影響. Prog Med 2007; 27: 1023-1029.

16) 湯浅麻奈美, 安江正明, 池田満雄ら. 難消化性デキストリ ン茶摂取の食後血糖值への影響扣よび長期連続摂取時の安 全性. 日本食品新素材研究会誌. 2004; 7: 83-93.

17) 山崎祥史, 福田真一, 白石浩荘ら. 難消化性デキストリン を配合した米菓の摂取が健常成人の食後血糖值に与学る影 響扣よび継続摂取時の安全性. 日本食品新素材研究会誌. 2004; 7: 105-111.

18）中川致之, 大河原雅晴, 北川雄一郎ら。難消化性デキスト リン含有緑茶飲料摂取の食後血糖值への影響扣よび長期連 続摂取の安全性への影響. 健康・栄養食品研究. 2003; 6: 1-8.

19）川崎史子，松田昌文，平松智子ら，難消化性デキストリン 配合茶飲料の有用性の検討一食後血糖值上昇反応およびそ の他血中成分に及ぼす影響一. 健康・栄養食品研究. 2000; 3: $1-8$.

20) 竹内治男, 佐野 淳, 仲村太志ら. 難消化性デキストリン 含有茶飲料のデンプン質食品摂取後の血糖值に及ぼす影 響. 健康・栄養食品研究. 2001; 4: 1-9.

21）近藤 敦, 栗原昭一, 佐藤紘子ら. 難消化性デキストリン 添加飲料の健常人食後血糖に与える影響. 日本食生活学会 誌. 2003; 14: 221-225.

22）塩田紀子, 清水宗茂, 清水郁子ら. 難消化性デキストリン 配合ヨーグルト飲料の食後血糖值上昇に及ぼす影響. 健康・ 栄養食品研究. 2001; 4: 1-11.

23）篠原久実, 辻 宏明, 瀬戸 明. 難消化性デキストリン添 加緑茶の食後血糖上昇に及ぼす影響. 健康・栄養食品研究. 1999; 2: 52-56.

24）山崎祥史, 福田真一, 白石浩荘ら. 難消化性デキストリン を配合した米菓の摂取が健常成人の食後血糖值に与える影 響 一米菓 $80 \mathrm{kcal}$ 摂取に抢ける検討一. 生活衛生. 2006; 50: 18-22. 


\author{
ABSTRACT \\ Foods for Specialized Health Use (FOSHU) in Treating Postprandial Elevated Blood \\ Glucose Level \\ Hirotaka HAYASHI ${ }^{1,2}$, Satoshi OHNO ${ }^{2}$, Takanari ARAI ${ }^{3}$, Masuo NAKAI ${ }^{4}$, Yoshiko KATO², Nobutaka SUZUKI ${ }^{2}$ \\ ${ }^{1}$ Center for Innovation, Kanazawa University \\ ${ }^{2}$ Department of Complementary and Alternative Medicine Clinical Research and \\ Development, Kanazawa University Graduate School of Medical Science \\ ${ }^{3}$ Center for the Advancement of Pregnancy, Perinatal and Infant Care, Kanazawa \\ University Hospital \\ ${ }^{4}$ Hoju Memorial Hospital
}

Approximately 100 kinds of Foods for Specified Health Use (FOSHU) are used to "control postprandial elevated blood glucose level". In this review, we describe their safety and effectiveness.

Key words: food for specified health use, postprandial glucose level, involvement component, indigestible dextrin, poly phenol in guava leaves, wheat albumin, touchi extract 